Check for updates

Cite this: RSC Adv., 2020, 10, 38013

Received 17th September 2020 Accepted 8th October 2020

DOI: 10.1039/d0ra07973a

rsc.li/rsc-advances

\section{Homogeneous and heterogeneous molecular catalysts for electrochemical reduction of carbon dioxide}

\begin{abstract}
Maryam Abdinejad, M. Nur Hossain and Heinz-Bernhard Kraatz (DD*
Carbon dioxide $\left(\mathrm{CO}_{2}\right)$ is a greenhouse gas whose presence in the atmosphere significantly contributes to climate change. Developing sustainable, cost-effective pathways to convert $\mathrm{CO}_{2}$ into higher value chemicals is essential to curb its atmospheric presence. Electrochemical $\mathrm{CO}_{2}$ reduction to value-added chemicals using molecular catalysis currently attracts a lot of attention, since it provides an efficient and promising way to increase $\mathrm{CO}_{2}$ utilization. Introducing amino groups as substituents to molecular catalysts is a promising approach towards improving capture and reduction of $\mathrm{CO}_{2}$. This review explores recently developed state-of-the-art molecular catalysts with a focus on heterogeneous and homogeneous amine molecular catalysts for electroreduction of $\mathrm{CO}_{2}$. The relationship between the structural properties of the molecular catalysts and $\mathrm{CO}_{2}$ electroreduction will be highlighted in this review. We will also discuss recent advances in the heterogeneous field by examining different immobilization techniques and their relation with molecular structure and conductive effects.
\end{abstract}

\section{Introduction}

Carbon dioxide $\left(\mathrm{CO}_{2}\right)$, as a greenhouse gas, is a significant contributor to climate change. The global average atmospheric $\mathrm{CO}_{2}$ level in 2019 was $409.8 \mathrm{ppm}$, much higher than the previous highest concentration of $300 \mathrm{ppm}$, with levels projected to keep increasing unless immediate measures are taken. ${ }^{1,2}$ These emission levels have raised serious environmental concerns and have translated to noticeable, aberrant meteorological changes.

Recent strategies that convert $\mathrm{CO}_{2}$ into value-added materials using photochemically ${ }^{3}$ or electrochemically ${ }^{4-6}$ powered reduction reactions have shown promise in recent years. However, this task is challenging due to the high energy required $\left(750 \mathrm{~kJ} \mathrm{~mol}^{-1}\right)$ to break the $\mathrm{C}=\mathrm{O}$ bond $^{7,8}$ and the molecule's stable linear geometry, which makes $\mathrm{CO}_{2}$ reduction reactions $\left(\mathrm{CO}_{2} \mathrm{RRs}\right)$ sluggish and challenging. ${ }^{3,9}$ Additionally, the electrocatalytic $\mathrm{CO}_{2}$ reduction mechanism is a complex process that involves multiple proton-coupled electron transfer steps and may include several side-reactions and intermediates. ${ }^{10-14}$

The first step of many $\mathrm{CO}_{2} \mathrm{RRs}$ is the one-electron reduction of $\mathrm{CO}_{2}$ to a $\mathrm{CO}_{2}{ }^{--}$radical anion which has a more reactive, bent geometry (Table 1). ${ }^{15,16}$ Although most $\mathrm{CO}_{2}$ RRs describe twoelectron reduction to carbon monoxide (CO) and formaldehyde, products of multi-electron transformations such as

Department of Physical and Environmental Sciences, University of Toronto Scarborough, 1265 Military Trail, Toronto, ON M1C 1A4, Canada. E-mail: bernie. kraatz@utoronto.ca methane,${ }^{17}$ methanol ${ }^{18}$ and ethano ${ }^{19}$ are highly coveted. Table 1 shows the theoretical potentials required to form various multielectron reductions. Although the theoretical potentials required to form the target products shown in Table 1 appear relatively low, because the products formed are often either thermodynamically similar or more stable than $\mathrm{CO}_{2}$, more negative potentials are required for practical applications to obtain reasonable reaction rates. ${ }^{9}$ In order to facilitate $\mathrm{CO}_{2} \mathrm{RR}$, the use of catalysts is essential and serves several purposes including lowering activation energy barriers, improving reaction rates, and increasing product selectivity. ${ }^{20-23}$

Electroreduction of $\mathrm{CO}_{2} \mathrm{RR}$ can be completed using either homogeneous or heterogeneous catalysts. Although homogeneous catalysis have shown high selectivity, with near product unity for the production of $\mathrm{CO}$ and other reduction products, ${ }^{18,25-29}$ these systems are dependent on the solubility constraints of the catalysts and are limited by low current densities and instability. ${ }^{30}$ On the other hand, heterogeneous

Table 1 Electrochemical potentials of possible $\mathrm{CO}_{2} \mathrm{RR}$ in aqueous solutions ${ }^{24}$

\begin{tabular}{ll}
$\mathrm{CO}_{2}$ reduction half-reactions & $\begin{array}{l}\text { Electrode potentials } \\
(\mathrm{V} v \text { vs. NHE) at } \mathrm{pH}=7\end{array}$ \\
\hline $\mathrm{CO}_{2}+\mathrm{e}^{-} \rightarrow \mathrm{CO}_{2}^{--}$ & -1.90 \\
$\mathrm{CO}_{2}+2 \mathrm{H}^{+}+2 \mathrm{e}^{-} \rightarrow \mathrm{HCO}_{2} \mathrm{H}$ & -0.61 \\
$\mathrm{CO}_{2}+2 \mathrm{H}^{+}+2 \mathrm{e}^{-} \rightarrow \mathrm{CO}+\mathrm{H}_{2} \mathrm{O}$ & -0.53 \\
$\mathrm{CO}_{2}+4 \mathrm{H}^{+}+4 \mathrm{e}^{-} \rightarrow \mathrm{HCHO}+\mathrm{H}_{2} \mathrm{O}$ & -0.48 \\
$\mathrm{CO}_{2}+6 \mathrm{H}^{+}+6 \mathrm{e}^{-} \rightarrow \mathrm{CH}_{3} \mathrm{OH}+\mathrm{H}_{2} \mathrm{O}$ & -0.38 \\
$\mathrm{CO}_{2}+8 \mathrm{H}^{+}+8 \mathrm{e}^{-} \rightarrow \mathrm{CH}_{4}+2 \mathrm{H}_{2} \mathrm{O}$ & -0.24
\end{tabular}


electrocatalysts minimize the electrode and catalyst distance, allowing for more efficient processes and higher current densities at the expense of product selectivity. ${ }^{31-33}$ In either case, although a variety of electrocatalysts have been introduced for $\mathrm{CO}_{2} \mathrm{RR}$ in recent decades, ${ }^{34-36}$ the performance of these systems has yet to reach a level where they can be successfully implemented industrially. ${ }^{37,38}$

Recent advancements have found success through incorporating a combination of molecular catalysts and heterogeneous immobilization strategies. ${ }^{\mathbf{3 9}-\mathbf{4 1}}$ Different molecular approaches such as metal organic frameworks (MOFs), covalent organic frameworks (COFs), and metal-free catalysts have tried to address this issue..$^{31,42-45}$ It has been shown that applying organic compounds, such as thiols, ${ }^{46,47}$ polypyrrole, ${ }^{48}$ $\mathrm{N}$-heterocyclic carbenes (NHCs), ${ }^{49}$ and N-substituted pyridines, ${ }^{17,50,51}$ can reduce $\mathrm{CO}_{2}$ to desirable materials such $\mathrm{CO}$, $\mathrm{HCOO}^{-}$and $\mathrm{COOH}$.

The amino functional group in particular has proven to be effective at selectively capturing $\mathrm{CO}_{2}$ from a mixture of gases. This ability is especially pronounced in primary or secondary amines such as monoethanolamine (MEA), diethanolamine (DEA) and decylamine (DCA). ${ }^{52-57}$ In these reactions, the amino groups initially capture $\mathrm{CO}_{2}$ to form a zwitterionic species that can react with another amino equivalent to form a carbamate salt (Scheme 1). ${ }^{\mathbf{5 8 , 5 9}}$

This review will start with a general introduction to the electrochemical reduction of $\mathrm{CO}_{2}$ and the metrics that are used to quantify catalyst efficiency and continue with a summary of the recent developments of amine molecular catalysts in both homogeneous and heterogeneous environments. In general, this report suggests that structural tuning of organic compounds followed by either covalent or non-covalent immobilization onto various conductive surfaces (i.e., graphite, $\mathrm{Au}, \mathrm{Ag}, \mathrm{Pd}$, and $\mathrm{Cu}$ ), results in high performing systems.

\section{Electroreduction of carbon dioxide}

Electrochemical capture and reduction of $\mathrm{CO}_{2}{ }^{60}$ has received extensive interest in the last decade because of the: (1) controllable nature of the technique (e.g. potential and temperature); (2) flexibility between organic and aqueous media; (3) relative scalability of bench-side reaction setups to industrial application. ${ }^{61}$

Typical electrochemical cells consist of a cathode, anode, electrolyte and a membrane (Fig. 1). $\mathrm{CO}_{2} \mathrm{RR}$ occurs at the cathode, while reciprocal oxidation or oxygen evolution reactions (OERs) occur at the anode. The cathode and the anode are separated by a membrane which maintains charge balance and separates the respective redox products. The electrolyte carries the charge between the electrodes and delivers dissolved $\mathrm{CO}_{2}$ to the catalytically active surface.

$$
\mathrm{RNH}_{2}+\mathrm{CO}_{2} \rightleftharpoons \stackrel{+}{\mathrm{RN}_{2}} \mathrm{CO} \overline{\mathrm{O}} \stackrel{\mathrm{RNH}_{2}}{\rightleftharpoons} \mathrm{RNHCO} \overline{\mathrm{O}}+\stackrel{+}{\mathrm{RN}^{+}} \mathrm{H}_{3}
$$

Scheme 1 Carbamate formation using primary and secondary amines.

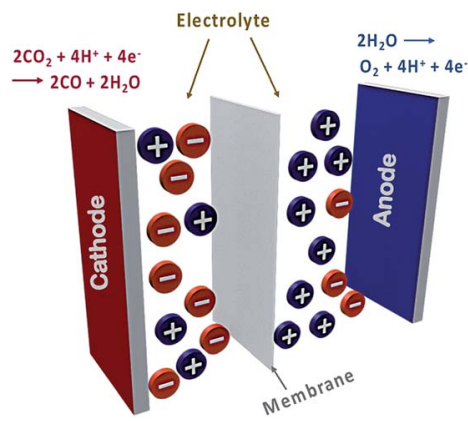

Fig. 1 A typical electrochemical $\mathrm{CO}_{2}$ reduction reaction cell. The oxidation and reduction occur at anode and cathode, respectively. The membrane separates the compartments. The electrolyte includes positive and negative species that assist charge and $\mathrm{CO}_{2}$ transport

\section{Quantifying catalytic performance}

Several factors are used to quantify catalytic performance. Selectivity is measured by the faradaic efficiency (FE), and the catalyst activity is determined by the current density $(j)$ as a function of the electrode area. The current density can be used to describe either the total current density of all reduced products or the partial current density of one particular product. In the context of $\mathrm{CO}_{2} \mathrm{RR}$, current density can be used to describe the rate of reaction. The robustness of the catalyst is calculated with the turnover number (TON) which is determined by dividing the mole of reduced product with the mole of catalyst. The turnover frequency (TOF, $\mathrm{s}^{-1}$ ) is defined as the mole of reduction product divided by the mole of active catalysts per unit of time.

\section{Molecular electrocatalysis for $\mathrm{CO}_{2} \mathrm{RR}$}

Using electrochemical techniques to reduce captured $\mathrm{CO}_{2}$ with small molecules is a promising strategy to produce valuable materials. ${ }^{62}$ This has been demonstrated previously using amino and pyridine-substituted compounds for electrochemical $\mathrm{CO}_{2} \mathrm{RR}$ in both homogeneous and heterogeneous media. ${ }^{18,63-69}$

Various catalysts have been developed as both homogeneous molecular catalysts ${ }^{\mathbf{1 6 , 1 8 , 7 0 - 7 7}}$ and heterogeneous solid-state catalysts, ${ }^{22,40,78}$ such as metal alloys, ${ }^{79,80}$ non-metal catalysts ${ }^{81}$ and single atoms. ${ }^{82}$ The identity of the metal electrodes have also been shown to play a role in the product distribution. ${ }^{12,83-93}$ In this section, recent developments in molecular electrocatalysts for $\mathrm{CO}_{2}$ reduction will be discussed with respect to their molecular structure, nano-structuring immobilization and electrode surface modification. The study of the following molecular catalysts highlights the importance of molecular design, electronic factors, and ligand structure in successful experimental design.

\subsection{Homogeneous amine molecular catalysts and electrochemical $\mathrm{CO}_{2} \mathrm{RR}$}

Homogeneous studies of amine-based molecular electrocatalysts have been identified their utility for $\mathrm{CO}_{2} \mathrm{RR}$. Using 
meso-substituted amino groups on metallated porphyrins, we were able to achieve selective reduction of $\mathrm{CO}_{2}$ to $\mathrm{CO}$ and methanol (Fig. 2a). ${ }^{18}$ Comparing the cyclic voltammograms of Co-TPP and Co-TPP- $\mathrm{NH}_{2}$ in the presence of $\mathrm{CO}_{2}$ clearly highlights the importance of the amino group and its role in reducing $\mathrm{CO}_{2}$ (Fig. 2b). The influential presence of the cobalt center in $\mathrm{CO}_{2} \mathrm{RR}$, can be seen in Fig. 2d. In this project, $\mathrm{H}_{2} \mathrm{O}$ was used as an extra proton source to facilitate the $\mathrm{C}-\mathrm{O}$ bond cleavage (Fig. 2e). To further understand the electroactivity of the amino group, a comparison with nitro porphyrins (TPP$\mathrm{NO}_{2}$ ) shows a slightly better performance of the amino group (Fig. 2f).

Chapovetsky et $a .^{94}$ also reported a cobalt aminopyridine macrocycle with amine substituents selectively reducing $\mathrm{CO}_{2}$ to CO. From electrochemical experiments, they found that the catalytic activity is strongly dependent on the number of secondary amines (Fig. 3). ${ }^{95}$ Subsequent studies showed how those amine groups could act as hydrogen bond donors to enhance catalytic performance.

The identity of the electrode used has been found to have a large influence on the catalytic activity of homogeneous amine solutions, with different electrodes such as glassy carbon, copper, and silver each eliciting their own distinctive response..$^{18,46,55,63,96-101}$ Lue et $a l .{ }^{55}$ reported a systematic study on electrochemical $\mathrm{CO}_{2}$ reduction with $30 \%$ (w/w) MEA on, $\mathrm{Sn}, \mathrm{Pb}$, $\mathrm{Pd}, \mathrm{Ag}, \mathrm{Cu}$ and $\mathrm{Zn}$ metal electrodes. Schmitt et al. ${ }^{\mathbf{1 0 0}}$ used in situ surface-enhanced Raman spectroscopy to study 3,5-diamino1,2,4-triazole (DAT) exposed-Ag electrodes, finding that the amine treated electrode increased $\mathrm{FE}_{\mathrm{CO}}$ due to a weakening of the CO bonding strength.

Many studies of copper $(\mathrm{Cu})$ electrodes have characterized their ability to reduce $\mathrm{CO}_{2}$ to multi-carbon products, ${ }^{14,33,55,87,102-110}$ whereas when exposed to molecular catalysts it is more common to see $\mathrm{CO}_{2}$ selectively converted to $\mathrm{CO},{ }^{57}$ formate, ${ }^{111}$ and formic acid. ${ }^{13,104}$ We have also investigated the ability of primary amines to selectively reduce $\mathrm{CO}_{2}$ to $\mathrm{CO}$ using

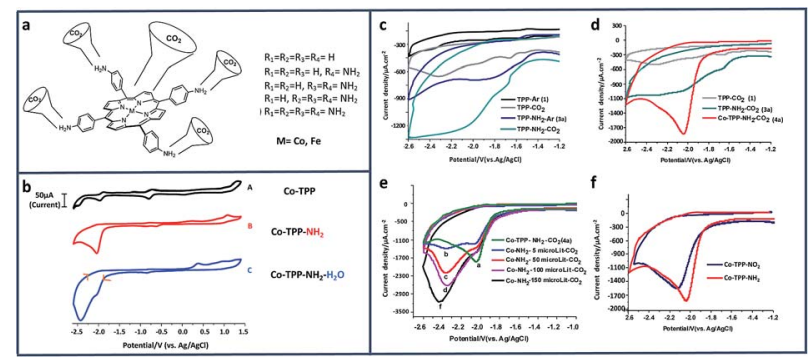

Fig. 2 (a) Schematic of metallated amino porphyrins; cyclic voltammograms (CV) of $0.01 \mathrm{mM}$ of (b) Co-TPP, Co-TPP- $\mathrm{NH}_{2}$, and Co-TPP$\mathrm{NH}_{2}$ with $5 \% \mathrm{H}_{2} \mathrm{O}$; under $\mathrm{CO}_{2}$; (c) comparison of TPP and TPP- $\mathrm{NH}_{2}$ under $\mathrm{Ar}$ and $\mathrm{CO}_{2}$; (d) comparison of TPP, TPP- $\mathrm{NH}_{2}$, and $\mathrm{Co}-\mathrm{TPP}-$ $\mathrm{NH}_{2}$ under $\mathrm{Ar}$ and $\mathrm{CO}_{2}$; (e) $\mathrm{Co}-\mathrm{TPP}-\mathrm{NH}_{2}$ in $0.1 \mathrm{M} \mathrm{NBu}_{4} \mathrm{PF}_{6}$ in DMF solutions at a scan rate of $100 \mathrm{mVs}^{-1}$ in: (a) (no water), (b) $5 \mu \mathrm{L}$ (C) $50 \mu \mathrm{L}$ (d) 100 (e) $150 \mu \mathrm{L}$ water. (f) Comparison of Co-TPP-NO $\mathrm{NO}_{2}$ and Co-TPP$\mathrm{NH}_{2}$ under $\mathrm{Ar}$ and $\mathrm{CO}_{2}$ in $0.1 \mathrm{M} \mathrm{NBu}_{4} \mathrm{PF}_{6}$ and DMF solutions. Conditions: scan rate, $100 \mathrm{mV} \mathrm{s}{ }^{-1}$; working electrode, glassy carbon; reference electrode, $\mathrm{Ag} / \mathrm{AgCl}$; counter electrode, platinum. ${ }^{18}$ Copyright (2019) American Chemical Society.

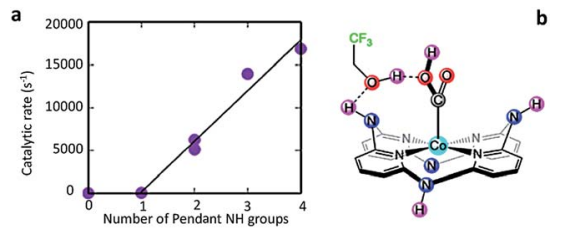

Fig. 3 (a) Experimental catalytic rate constants, $k_{\mathrm{obs}}\left(\mathrm{s}^{-1}\right)$, as a function of the number of pendant secondary amines using 1.5 M TFE under $\mathrm{CO}_{2}$ saturation at a scan rate of $100 \mathrm{mV} \mathrm{s}^{-1}$. (b) Schematic of pendant hydrogen-bond donors in cobalt catalysts independently enhance $\mathrm{CO}_{2}$ electroreduction. ${ }^{95}$ Copyright (2018) American Chemical Society.

Cu electrodes (Fig. 4). ${ }^{57}$ In these studies, ethylenediamine (EDA) proved to be the most effective absorbent for $\mathrm{CO}_{2}$ capture and subsequent reduction to $\mathrm{CO}$ among MEA and decylamine (DCA), with a current density of $-18 \mathrm{~mA} \mathrm{~cm}^{-2}$, TON of 252 and a $\mathrm{FE}$ of $58 \%$ at $-0.78 \mathrm{~V}$ vs. RHE. Compared to glassy carbon electrodes, the cathodic current was dramatically enhanced when $\mathrm{Cu}$ was used as a working electrode (Fig. $4 \mathrm{f}$ and $\mathrm{g}$ ).

Our recent studies on the electrochemical reduction of $\mathrm{CO}_{2}$ in various fractions of MEA solutions at smooth and nanodendrite (ND) $\mathrm{Cu}, \mathrm{Ag}$ and $\mathrm{Au}$ showed that a $0.05 \mathrm{M}$ fraction of MEA exhibited the highest catalytic activity for each surface. ${ }^{\mathbf{1 1 2}}$ $\mathrm{CO}_{2}$ electroreduction to $\mathrm{HCOO}^{-}$. The ND electrodes exhibited much higher current efficiencies for $\mathrm{CO}_{2}$ to $\mathrm{HCOO}^{-}$conversion compared to the smooth metal electrodes, revealing the critical role of surface morphology in enhancing catalytic activity.

\subsection{Heterogeneous amine molecular catalysts and electrochemical $\mathrm{CO}_{2} \mathrm{RR}$}

Heterogeneous electrocatalysts have benefits over homogeneous electrocatalysts for $\mathrm{CO}_{2} \mathrm{RR}$ application due to the catalytically active site being either located directly on the electrode surface or the electrode itself. As a result, catalytic loading concentrations can be lower. Molecular catalysts can be

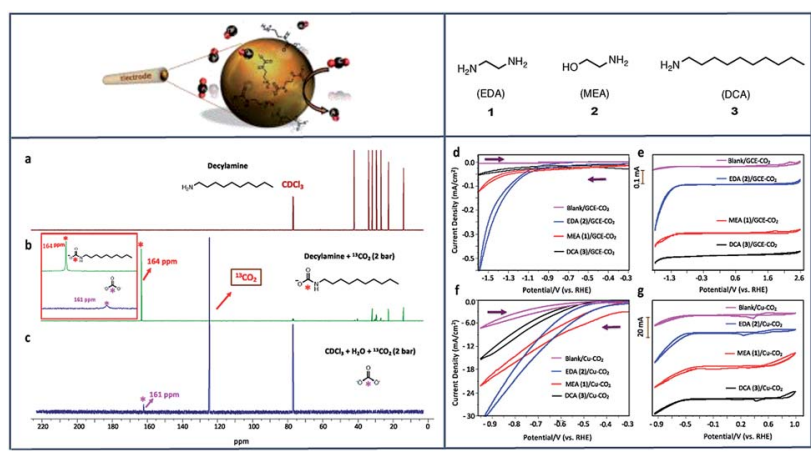

Fig. $4{ }^{13} \mathrm{C}$ NMR spectra of DCA (a), DCA $-{ }^{13} \mathrm{CO}_{2}$ (b) and $\mathrm{H}_{2} \mathrm{O}-{ }^{13} \mathrm{CO}_{2}$ (c) in $\mathrm{CDCl}_{3}$. Cyclic voltammograms (CV) of: (d) $1-3$ under $\mathrm{CO}_{2}$ with $\mathrm{GCE}$; (e) compounds 1-3 under $\mathrm{CO}_{2}$ with GCE stacked; (f) 1-3 under $\mathrm{CO}_{2}$ with $\mathrm{Cu}$ electrode; (g) 1-3 under $\mathrm{CO}_{2}$ with $\mathrm{Cu}$ electrode stacked; $0.1 \mathrm{mM}$ concentration in $0.1 \mathrm{M} \mathrm{NaClO}_{4}$ solution. Conditions: scan rate, $100 \mathrm{mVs}^{-1}$; working electrode, glassy carbon/copper; reference electrode, $\mathrm{Ag} / \mathrm{AgCl}$; counter electrode, platinum. ${ }^{57}$ Copyright (2020) American Chemical Society. 
attached to solid, conductive surfaces via covalent/non-covalent immobilization techniques ${ }^{\mathbf{2 9 , 1 1 3 , 1 1 4}}$ or using polymers and metal-organic frameworks. ${ }^{\mathbf{1 1 5 - 1 1 7}}$ This strategy offers higher stability and catalytic efficiency ${ }^{56}$ with a greater potential of reaching the necessary current densities for industrial implementation. ${ }^{118}$ Due to its simple preparations, one of the most popular immobilization techniques involves depositing conjugated organic ligands onto carbon surfaces which are stabilized by the non-covalent $\pi-\pi$ interactions between the catalyst and solid surface. ${ }^{17,56,119}$ The molecular catalysts can be also deposited on electrode surfaces through covalent bond. ${ }^{\mathbf{1 2 0 , 1 2 1}}$

Previous reports on $\mathrm{CO}_{2} \mathrm{RR}$ selectivity involved either the use of a metal electrode surface, where the electron-transfer efficiency was largely dependent on the material's conductivity, or the incorporation of small inactive molecules ${ }^{39}$ on the surface of the metal electrode to maximize interaction between the electrode and the molecular catalysts. ${ }^{56,61,122-125}$ An example of this are electrografting techniques which produce a direct chemical bond between the catalyst and a solid substrate. ${ }^{\mathbf{9 8 , 1 2 6}}$ The direct connections that arise from these methods are believed to be the primary factor in increasing the reaction rate of $\mathrm{CO}_{2} \mathrm{RR}$ relative to hydrogen evolution reactions (HERs) and lowering overpotentials. ${ }^{\mathbf{1 2 5 , 1 2 7 - 1 3 1}}$ Using this technique, immobilization of terpyridine onto glassy carbon electrodes has been previously reported. ${ }^{66}$

Marianov et al. ${ }^{\mathbf{1 2 1}}$ have also successfully electrografted amino porphyrins via electro reduction of diazonium salt onto glassy carbon (Scheme 2). By introducing a conjugated linker between the porphyrin and the electrode, they proved that the $\mathrm{Co}^{\mathrm{I}} / \mathrm{Co}^{\mathrm{II}}$ redox couple facilitates the $\mathrm{CO}_{2}$ electroreduction process (Fig. 5a). With the covalently linked catalyst an increase to the current density $\left(4.7 \mathrm{~mA} \mathrm{~cm} \mathrm{~cm}^{-2}\right)$ was seen, compared to the unlinked catalysts $\left(1.4 \mathrm{~mA} \mathrm{~cm}^{-2}\right)$ (Fig. $\left.5 \mathrm{~b}\right)$. In addition to the covalent linkage facilitating electrode-to-catalyst charge transfer, the current density was also observed to be dependent on the catalyst loading concentration and the total active surface area (Fig. $5 \mathrm{~b}$ and c).

Zouaoui et al. ${ }^{97}$ investigated the electrocatalytic activity of amine derivatives deposited onto $\mathrm{Pb}$ surfaces toward electroreduction of $\mathrm{CO}_{2}$ to formate. Using diazonium chemistry, 4aminomethylbenzene (4-ABA), 3-aminomethylbenzene (3-ABA), 4-(2-aminoethyl)benzene (4-AEA) and 4-nitrobenzene (4-NB) were grafted onto $\mathrm{Pb}$ electrodes (Fig. 6). The $\mathrm{Pb}$-amine modified electrodes showed enhanced activity and selectivity in all cases (Fig. 6a). Fig. 6b shows chronoamperograms of the 4-ABA modified $\mathrm{Pb}$ electrode $\left(6.3 \times 10^{-7} \mathrm{~mol} \mathrm{~cm}{ }^{-2}\right)$ in a $1 \mathrm{M} \mathrm{HKCO}_{3}$ solution saturated with $\mathrm{CO}_{2}$. In this study, 4-ABA reached

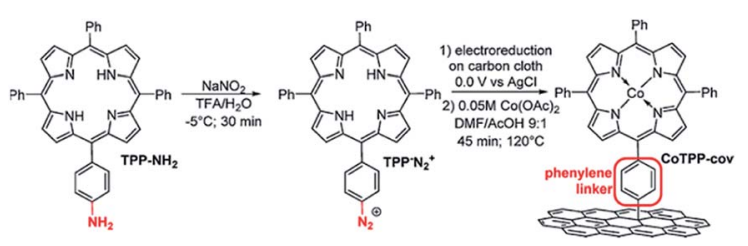

Scheme 2 Preparation of covalently immobilized Co tetraphenylporphyrin (CoTPP-cov). ${ }^{121}$ Copyright (2019) Elsevier.

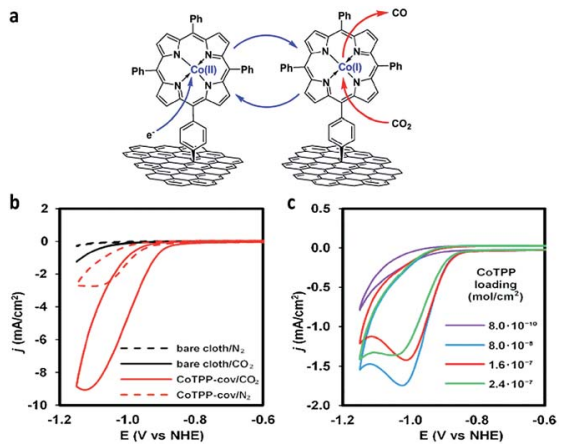

Fig. 5 (a) Preparation of covalently immobilised Co tetraphenylporphyrin (CoTPP-cov); (b) CVs of CoTPP-cov in $\mathrm{N}_{2}$ - and $\mathrm{CO}_{2}$-purged aqueous electrolyte, CVs of bare carbon cloth are shown for clarity; (c) $\mathrm{CV}$ traces of CoTPP-noncov with the variable amount of noncovalently immobilized CoTPP in $\mathrm{CO}_{2}$-saturated solution. Conditions: electrolyte: $0.5 \mathrm{M} \mathrm{KHCO}_{3}$ in all cases, potential scan rate is $100 \mathrm{mV} \mathrm{s}^{-1}$. ${ }^{121}$ Copyright (2019) Elsevier.

a maximum current density of $-24 \mathrm{~mA} \mathrm{~cm}^{-2}$ at $-1.29 \mathrm{~V} v s$. RHE, with a FE over $80 \%$ (Fig. 6c and d).

Gold $(\mathrm{Au})$ has been also found to exhibit catalytic activity towards $\mathrm{CO}_{2}$ RR. $^{132-134}$ Mikoshiba et al. ${ }^{135}$ showed that imidazolium ions immobilized on Au electrodes suppress $\mathrm{H}_{2}$ generation and accelerate $\mathrm{CO}_{2} \mathrm{RR}$. In their study, imidazolium salts with small methylene units (IL-2, Fig. 7A) exhibited greater current densities compared to longer chained units with FEs up to $87 \%$ (Fig. 7B).

In another study, Au electrodes functionalized with 4-pyridinylethanemercaptan (PEM) thiols showed similar increases in product selectivity and catalytic activity (Fig. 8a). ${ }^{\mathbf{1 3 6}}$ The proposed mechanism for formate production shows the pyridine $\mathrm{H}$-atom abstracted by reduction of the aqueous solution

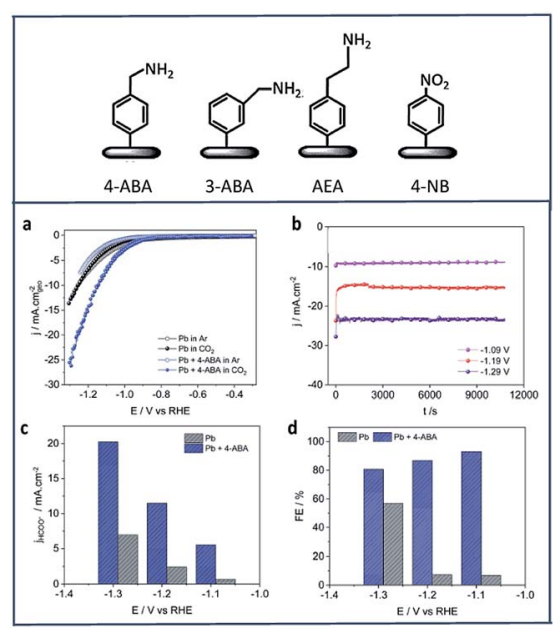

Fig. 6 The four different amines used in this work to modify the $\mathrm{Pb}$ electrodes: (a) $\mathrm{CV}$ of $\mathrm{Pb}$ and $\mathrm{Pb}+4-\mathrm{ABA}$; (b) chronoamperograms recorded in $\mathrm{CO}_{2}$-saturated $1 \mathrm{M} \mathrm{HKCO}_{3}$ solution for $\mathrm{Pb}+4-\mathrm{ABA}$ electrode $\left(6.3 \times 10^{-7} \mathrm{~mol} \mathrm{~cm}{ }^{-2}\right)$; comparison of (c) current density and (d) faradic efficiency at different potentials for $=\mathrm{Pb}+4-\mathrm{ABA}$ and bare Pb electrodes. ${ }^{97}$ Copyright (2019) Royal Society of Chemistry. 
and adsorbed onto the Au surface (Fig. 8a). $\mathrm{HCO}_{2}$ is formed through electrophilic attack of $\mathrm{CO}_{2}$ onto the adsorbed proton. The FE of the electroreduction products in this system were observed to be potential dependent. Fig. 8b-g shows the potential-dependent product distribution (formate, $\mathrm{CO}$ and $\mathrm{H}_{2}$ ) of functionalized $\mathrm{Au}$ and bare $\mathrm{Au}$ surfaces.

A 2-fold increase in $\mathrm{FE}_{\text {formate }}$ and a 3-fold increase in current density were achieved and attributed to enhancement of proton and electron transfers using $\mathrm{Au}$ foil (Fig. 8b and c). ${ }^{137}$ This increase in current density is due to the amine's ability to make a complex with $\mathrm{CO}_{2}$ near the Au surface. ${ }^{\mathbf{1 3 8}}$ Cystemine modified electrodes saw a 2 -fold increase in both $\mathrm{CO}$ and $\mathrm{H}_{2}$ production (Fig. 8d-f), while electrodes with 2-mercaptopropionic acid (MPA) ligands reported nearly $100 \%$ selectivity for $\mathrm{H}_{2}$ (Fig. 8g).

In another study, it was found that immobilization of $\mathrm{Au}$ nanoparticles using $\mathrm{N}$-heterocyclic carbenes facilitated electron transfer from $\mathrm{Au}$ to $\mathrm{CO}_{2}$ (Fig. 9a). ${ }^{\mathbf{1 3 9}}$ The electrochemical reduction of $\mathrm{CO}_{2}$ to $\mathrm{CO}$ catalysed by a Au-1,3-bis(2,4,6 trimethylphenyl)imidazol-2-ylidene nano particle ( $\mathrm{Au}-\mathrm{Cb} \mathrm{NP}$ ) was found to be greater than that of bare $\mathrm{Au}$ nanoparticles $\mathrm{Au}$ NP). Oleylamine-capped Au NPs (Au-Oa NP) were first loaded onto carbon black to make a $\mathrm{Au}-\mathrm{Oa} \mathrm{NP} / \mathrm{C}$ mixture. ${ }^{\mathbf{1 4 0}}$ The active surface area for $\mathrm{Au} \mathrm{NP/C}$ and Au-1,3-bis(2,4,6 trimethylphenyl) imidazol-2-ylidene nano particle $(\mathrm{Au}-\mathrm{Cb} \mathrm{NP})$ electrode were evaluated using $\mathrm{Pb}$ underpotential deposition (upd). ${ }^{141-143}$ The current density increased substantially (Fig. 9c and e) and the $\mathrm{FE}_{\mathrm{CO}}$ increased from $53 \%$ to $83 \%$ in when the $\mathrm{Au}$ nanoparticles were deposited onto $\mathrm{CB}$ (Fig. 9d). The kinetics of the $\mathrm{CO}_{2}$ reduction were examined using Tafel analysis (Fig. 9f) which shows a decreasing slope from $138 \mathrm{mV} \mathrm{dec}^{-1}$ to $72 \mathrm{mV} \mathrm{dec}^{-1}$.

Other promising active electrocatalytic systems incorporate $\mathrm{Ag}$ metal centers or $\mathrm{Ag}$ electrodes. ${ }^{\mathbf{4 7 , 6 3 , 1 4 4 - 1 4 7}}$ Compared to $\mathrm{Au}$ electrocatalysts, $\mathrm{Ag}$ catalyst are cheaper and have comparable activity. Various strategies, such as morphologynanostructuring have been paired with these electrodes. ${ }^{\mathbf{1 4 8 , 1 4 9}}$ Hwang and co-workers ${ }^{\mathbf{1 0 0}}$ prepared three different types of $\mathrm{Ag}$ nanoparticles with different surface capping agents. These included oleylamine (OLA), having an amine functional group; oleic acid, having a carboxyl functional group; and dodecanethiol (DDT) with a thiol functional group. They discovered

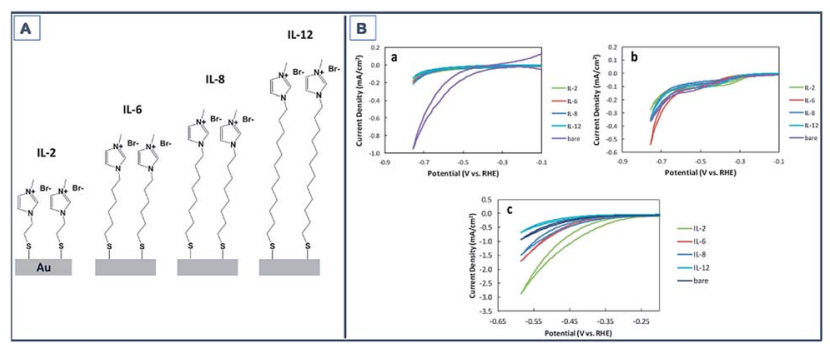

Fig. 7 Schematic of Au electrodes with 1-methylimidazolium-terminated SAMs (IL-2, IL-6, IL-8, and IL-12). CV of bare and SAM modified Au electrodes in $\mathrm{Na}_{2} \mathrm{SO}_{4}$ aqueous solution purged with (a) $\mathrm{N}_{2}$ and (b) $\mathrm{CO}_{2}$. Scan rate: $100 \mathrm{mV} \mathrm{s}^{-1}$; (c) $\mathrm{CV}$ of bare and SAM-modified $\mathrm{Au}$ electrodes in $\mathrm{NaHCO}_{3}$ aqueous solution purged with $\mathrm{CO}_{2}$. Scan rate: $100 \mathrm{mV} \mathrm{s}^{-1} .135$ Copyright (2015) Royal Society of Chemistry.

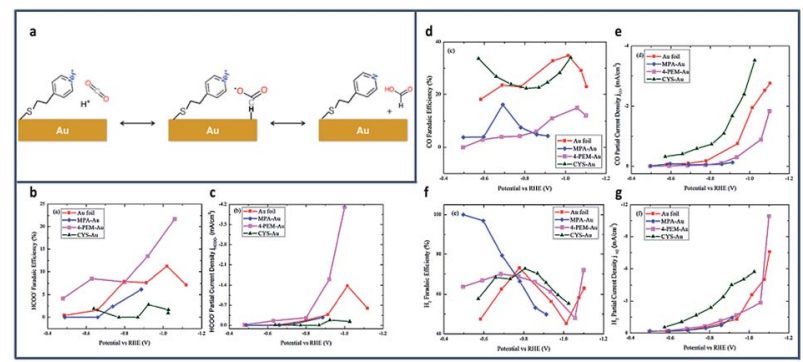

Fig. 8 (a) Proposed Mechanism for reduction to formate at PEMmodified Au Electrode; comparison of partial current density and FE for thiolate ligand on polycrystalline Au and pure polycrystalline Au: (b) FE of formate formation ( $\pm 2.5 \%$ at $95 \%$ confidence level $(C L))$, (c) FE of $\mathrm{CO}$ formation ( $\pm 6.2 \%$ at $95 \% \mathrm{CL}$ ), (d) $\mathrm{FE}$ of $\mathrm{H}_{2}$ formation ( $\pm 25 \%$ at $95 \%$ $\mathrm{CL}$ ); (e) partial current density of formate formation; (f) partial current density of $\mathrm{CO}$ formation, and (g) partial current density of $\mathrm{H}_{2}$ formation. ${ }^{136}$ Copyright (2020) American Chemical Society.

that the amine substituent was highly effective in enhancing the electrochemical reduction of $\mathrm{CO}_{2}$ to $\mathrm{CO}$ with high selectivity ( $\mathrm{FE}=94 \%)$ at low overpotentials $(-0.75 \mathrm{~V} v s$. RHE) due to an exceptional suppression of HER.

Comparing the mass activities of the $\mathrm{CO}$ and $\mathrm{H}_{2}$ products in Fig. 10d and e, HER suppression was observed at more negative potentials (lower than $-0.9 \mathrm{~V} v s$. RHE). DDT showed the highest CO partial mass activity compared to both OLA and the oleic acid (OA) at $-0.4 \mathrm{~V}$ to $-0.9 \mathrm{~V}$ vs. RHE (Fig. 10e). They also compared the immobilization of ethylenediamine (EDA) to cysteamine onto Ag nanoparticles and found that EDA showed a higher selectivity toward CO production due to the presence of the additional amine group.

Carbon-based materials such as CNTs have proven to be a promising conductive solid support for heterogenization of molecular catalysts toward electrochemical $\mathrm{CO}_{2} \mathrm{RR}$. This is due to their ability to form a strong noncovalent $\pi-\pi$ interactions with aromatic ligands such as pyrene $e^{\mathbf{1 5 0}}$ and porphyrin..$^{41,151} \mathrm{Hu}$

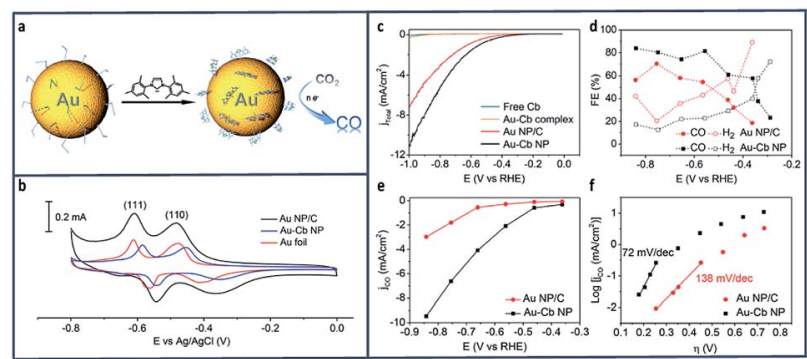

Fig. 9 (a) Schematic reduction of $\mathrm{CO}_{2}$ using $\mathrm{N}$-heterocyclic $(\mathrm{NHC})$ carbene-functionalized on a gold electrode. (b) $\mathrm{Pb}$-upd profiles of the $\mathrm{Au} N \mathrm{~N} / \mathrm{C}, \mathrm{Au}-\mathrm{Cb} \mathrm{NP}$, and $\mathrm{Au}-\mathrm{Cb} \mathrm{NP}$ was referenced to the geometric area of the Au foil with scan rate of $50 \mathrm{mV} \mathrm{s}^{-1}$ (c) LSV scans of $\mathrm{Au}-\mathrm{Cb}$ $\mathrm{NP}, \mathrm{Au} \mathrm{NP} / \mathrm{C}$, free carbene and molecular $\mathrm{Au}-\mathrm{Cb}$ complex under $\mathrm{CO}_{2}-$ saturated $0.1 \mathrm{M} \mathrm{KHCO}_{3}$ at $\mathrm{pH}$ 6.8. (d) FEs of reduction product formed from $\mathrm{Au}-\mathrm{Cb} \mathrm{NP}$ and Au NP/C. (e) Specific CO current density (based on electrochemically active surface area) plots for $\mathrm{Au}-\mathrm{Cb} N \mathrm{NP}$ and $\mathrm{Au}$ NP/C. (f) Tafel plots of $\mathrm{Au}-\mathrm{Cb}$ NP and Au NP/C. ${ }^{139}$ Copyright (2016) American Chemical Society. 


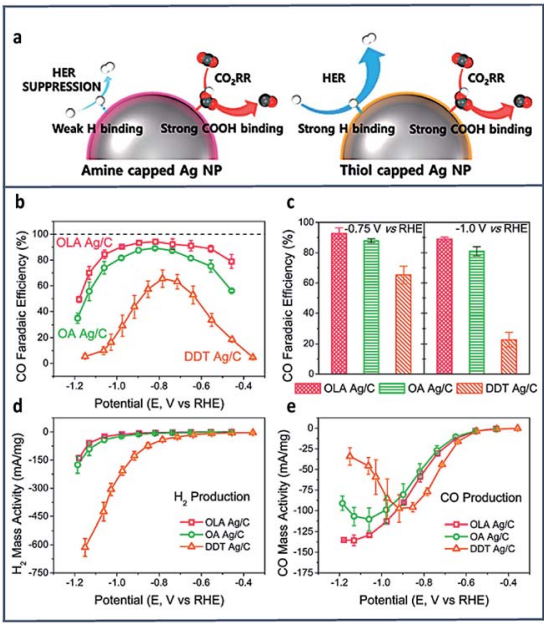

Fig. 10 (a) Schematic of $\mathrm{CO}_{2} \mathrm{RR}$ on amine and thiol-capped $\mathrm{Ag}$ nanoparticles. Variation of $\mathrm{FE}_{\mathrm{CO}}$ of OLA, OA and DDT Ag/C with (b) the applied voltage and (c) fixed potential. Mass activity for (d) $\mathrm{H}_{2}$ and (e) $\mathrm{CO}$ production of OLA, OA and DDT Ag/C at varied applied potentials. ${ }^{100}$ Copyright (2017) American Chemical Society.

et al. ${ }^{152}$ reported reduction of $\mathrm{CO}_{2}$ to $\mathrm{CO}$ with an efficiency of over $90 \%$ using immobilized cobalt-tetraphenylporphyrins (CoTPPs) onto CNT in aqueous solution. Likewise, previous work by our group demonstrates selective reduction of $\mathrm{CO}_{2}$ to $\mathrm{CO}$ with a $\mathrm{FE}$ of $90 \%$ upon immobilization of iron-porphyrindimers onto CNTs. ${ }^{56}$ This proved to be twice as efficient as when the same catalyst was applied in a homogenous medium.

Similar enhancements to the reduction of $\mathrm{CO}_{2}$ to methane $\left(\mathrm{CH}_{4}\right)$ and $\mathrm{CO}$ with both metalled and non-metallated ironporphyrin-pyridine (Fe-TPPy) catalysts were seen when noncovalently immobilized onto CNTs. ${ }^{17}$ Among the synthesized catalysts shown in Fig. 11a, Fe-cis (2b)-pyridine-porphyrin catalysts, exhibited the highest current density $\left(1.32 \mathrm{~mA} \mathrm{~cm}^{-2}\right)$ and $\mathrm{FE}(76 \%)$ in reducing $\mathrm{CO}_{2}$ to $\mathrm{CH}_{4}$ and $\mathrm{CO}$. Current density and product selectivity were remarkably enhanced to $30 \mathrm{~mA}$ $\mathrm{cm}^{-2}$ with the total $\mathrm{FE}$ of $92 \%$ after immobilization onto CNTs, comparable or higher than that of similarly reported catalysts.

Comparing the $\mathrm{CV}$ of non-metallated $2 \mathrm{a} / \mathrm{GCE}$ in Fig. $11 \mathrm{~b}$ under argon and $\mathrm{CO}_{2}$, an enhancement to the current density can be seen in the $\mathrm{CO}_{2}$ saturated solution stating at $\sim-0.8 \mathrm{~V} v s$. RHE. This increase in current density seen after purging $2 \mathrm{a} / \mathrm{GCE}$ with $\mathrm{CO}_{2}$ demonstrates the important role of pyridine in the capture and electroreduction of $\mathrm{CO}_{2}$ to methane. Metallated isomers increased the number of available capture sites and led to a direct increase in current density for all studied compounds (Fig. 11c). As seen in Fig. 11c, the broad $\mathrm{CO}_{2}$ reduction peak at $\sim-1.3 \mathrm{~V} v$ s. RHE aligns with the potential range observed for iron-cantered porphyrins.

Another report suggests using polyethylenimine (PEI) (Fig. 12a) will stabilize the electroreduction of $\mathrm{CO}_{2}$ to $\mathrm{HCOO}^{-}$ through hydrogen bonding interactions (Fig. 12b). ${ }^{153}$ As shown in Fig. 12c and d, PEI-NCNT had the highest current density $(9$ $\mathrm{mA} \mathrm{cm}^{-2}$ ) compared to nitrogen doped carbon nanotubes (NCNT) and bare CNT with a high FE of $87 \%$.

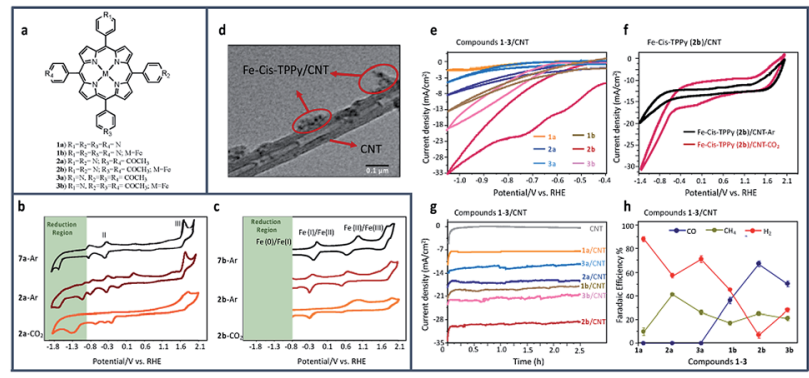

Fig. 11 (a) Molecular structure pyridine-porphyrin complexes (b) CV comparison of $0.01 \mathrm{mM}$ of TPP (7a)/GCE under argon, and cis-TPPy (2a)/GCE under argon and $\mathrm{CO}_{2}$; (c) Fe-TPP (7b)/GCE under argon, and Fe-cis-TPPy (2b)/GCE under argon and $\mathrm{CO}_{2}$ in $0.1 \mathrm{M} \mathrm{NBu}_{4} \mathrm{PF}_{6} / \mathrm{DMF}$ solution. Conditions: scan rate: $100 \mathrm{mV} \mathrm{s}^{-1}$; working electrode: glassy carbon; reference electrode: $\mathrm{Ag} / \mathrm{AgCl}$; counter electrode: platinum; (d) Transmission electtron microscopy (TEM) image of the porphyrin $2 \mathrm{~b} / \mathrm{CNT}$ with scale bar of $0.1 \mu \mathrm{m}$. CV comparison of (e) all compounds $1-3 / C N T$ under $\mathrm{CO}_{2}$; (f) compound $2 \mathrm{~b} / \mathrm{CNT}$ in the presence and absence of $\mathrm{CO}_{2} ; \mathrm{g}$ ) chronoamperometry comparison of $1-3 / \mathrm{CNT}$ at $-0.6 \mathrm{~V}$ vs. RHE; (h) FE comparison of all $1-3 / \mathrm{CNT}$ compounds at $-0.6 \mathrm{~V}$ vs. $\mathrm{RHE}$ in $0.1 \mathrm{M}$ aqueous $\mathrm{NaHCO}_{3} .{ }^{17}$ Copyright (2020) American Chemical Society

\subsection{Enhanced heterogeneous amine molecular catalysts using flow cells}

In addition to the aforementioned solid supports and immobilization techniques for heterogeneous molecular catalysis, use of flow cell electrolyzers is another technique that has been proven to enhance overall catalytic performance. This emerging system minimizes the distance between the electrode and the catalytic layer; combining efficient electrode-to-catalyst electron transfers with a continuous, single-pass directional $\mathrm{CO}_{2}$

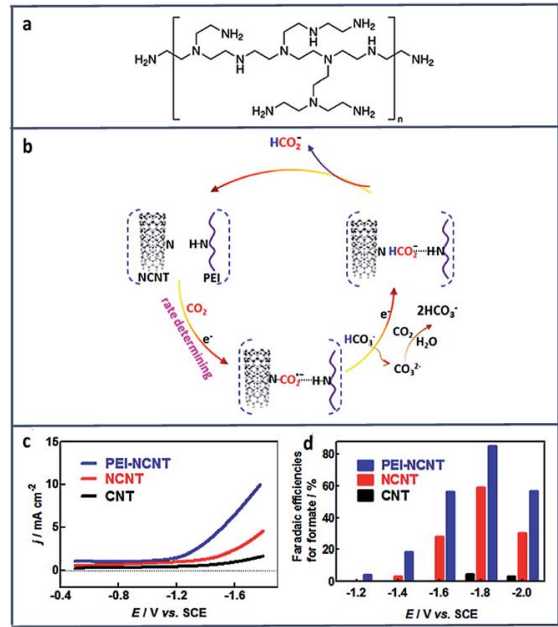

Fig. 12 (a) Structure of branched polyethylenimine (PEI). (b) Proposed mechanism for $\mathrm{CO}_{2}$ reduction at PEI Functionalized, nitrogen-doped carbon nanomaterials. (c) cathodic linear sweep voltammetry scans at $50 \mathrm{mV} \mathrm{s}^{-1}$ in a $\mathrm{CO}_{2}$-saturated aqueous $0.1 \mathrm{M} \mathrm{KHCO}_{3}$ solution. (d) Plot of faradaic efficiencies for formate production vs. applied potential at CNT/GC, NCNT/GC, and PEI-NCNT/GC electrodes. ${ }^{153}$ Copyright (2014) American Chemical Society. 


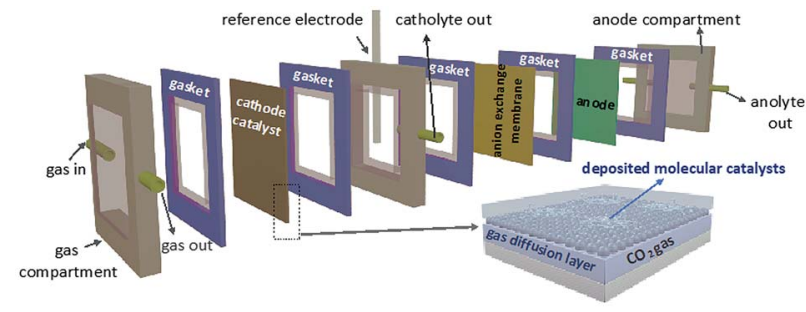

Fig. 13 Schematic of a flow cell. ${ }^{161}$ Copyright (2020) American Chemical Society.

delivery. These optimizations ultimately result in high energy efficiencies, product selectivities, and a reduction to operational costs. ${ }^{154-160}$ An additional benefit of flow cell electrolyzers is the translatability of their results to modern industrial practices. Generalized flow cell setups include a gas diffusion layer (GDL) which is directly exposed to the electrolyte solution (Fig. 13). ${ }^{161-163}$ The catalyst layer is typically deposited directly onto the GDL, allowing for a greater effective catalyst surface area.

Recent studies of molecular catalysts operated in flow cells find significant gains to both product selectivity and reaction conversion rate. Cobalt and iron porphyrin and phthalocyanine complexes deposited onto a gas diffusion electrode through non-covalent bonding in a flow cell have been reported to achieve high current densities and selectivities. ${ }^{164,165} \mathrm{An}$ example of immobilized cobalt and iron amino molecular catalysts on carbon paper supports report current densities up to $165 \mathrm{~mA}$ $\mathrm{cm}^{-2}$ while maintaining high product selectivity (up to 94\%). ${ }^{161,165}$ These results, confirm the importance of state-of-the-art noble molecular based catalysts for electrochemical $\mathrm{CO}_{2} \mathrm{RR}$.

\section{Conclusions and future prospects}

A wide range of amine-based molecular catalysts has been explored for the electrochemical reduction of $\mathrm{CO}_{2}$ over the years and the contributions of small molecule catalysis to finding insights into the mechanism of electrochemical $\mathrm{CO}_{2} \mathrm{RR}$ is instrumental to the intelligent design of new catalysts. In particular, the role of amine-based ligands and functional groups were found to play an important role in capturing $\mathrm{CO}_{2}$ itself and being used as covalent linkers for direct immobilization.

Although insights into the intricacies of $\mathrm{CO}_{2} \mathrm{RR}$ have been garnered thanks to thorough studies of immobilization techniques, the influence of metal electrodes, and the role of different metal centers in organometallic compounds, further improvements to catalytic activity and stability are still needed before large-scale application can be realized. As described in this review, noncovalent and covalent immobilization can be achieved through various techniques to positive effect. Expanding on this new approach, many renewed studies on both homogeneous and heterogeneous systems are gaining greater traction with promising bounds being made every year.
Various strategies can be considered to overcome the current limitations in the electrochemical reduction process for $\mathrm{CO}_{2}$ using amine-based molecular catalysts. For homogeneous electrocatalysis; (i) synthesizing small amine molecules that have a high affinity towards $\mathrm{CO}_{2}$ but have a weaker amine- $\mathrm{CO}_{2}$ bond; (ii) developing new nanostructured catalysts with large electrochemically active surface areas to facilitate the reduction process of the amine- $\mathrm{CO}_{2}$ at lower potentials and high catalytic activity and selectivity would be promising next steps. For heterogeneous systems: (i) developing facile synthetic approaches to amine-functionalized MOFs; (ii) preparing high amine content MOFs with improved chemical stability; and (iii) improving immobilization strategies with nanostructured materials instead of the smooth metal surfaces are recommended to achieve higher catalytic performance.

Therefore, further investigations are required to achieve high stability and catalytic activity of the amino electrocatalysts to understand the fundamental kinetics of $\mathrm{CO}_{2}$ reduction, and the effectiveness of the catalysts.

\section{Conflicts of interest}

There are no conflicts to declare.

\section{Acknowledgements}

We thank the Natural Science and Engineering Research Council (NSERC), and the University of Toronto ( $\mathrm{U}$ of T) for financial support.

\section{References}

1 S. J. Davis, K. Caldeira and H. D. Matthews, Science, 2010, 329, 1330-1333.

2 M. Ades, R. Adler, R. Allan, R. P. Allan, J. Anderson, A. Argüez, C. Arosio, J. A. Augustine, C. Azorin-Molina, J. Barichivich, J. Barnes, H. E. Beck, A. Becker, N. Bellouin, A. Benedetti, D. I. Berry, S. Blenkinsop, O. Bock, M. G. Bosilovich, O. Boucher, S. A. Buehler, L. Carrea, H. H. Christiansen, F. Chouza, J. R. Christy, E.-S. Chung, M. Coldewey-Egbers, G. P. Compo, O. R. Cooper, C. Covey, A. Crotwell, S. M. Davis, E. de Eyto, R. A. M. de Jeu, B. V. VanderSat, C. L. DeGasperi, D. Degenstein, L. Di Girolamo, M. T. Dokulil, M. G. Donat, W. A. Dorigo, I. Durre, G. S. Dutton, G. Duveiller, J. W. Elkins, V. E. Fioletov, J. Flemming, M. J. Foster, R. A. Frey, S. M. Frith, L. Froidevaux, J. Garforth, S. K. Gupta, L. Haimberger, B. D. Hall, I. Harris, A. K. Heidinger, D. L. Hemming, S. Ho, D. Hubert, D. F. Hurst, I. Hüser, A. Inness, K. Isaksen, V. John, P. D. Jones, J. W. Kaiser, S. Kelly, S. Khaykin, R. Kidd, H. Kim, Z. Kipling, B. M. Kraemer, D. P. Kratz, R. S. La Fuente, X. Lan, K. O. Lantz, T. Leblanc, B. Li, N. G. Loeb, C. S. Long, D. Loyola, W. Marszelewski, B. Martens, L. May, M. Mayer, M. F. McCabe, T. R. McVicar, C. A. Mears, W. P. Menzel, C. J. Merchant, B. R. Miller, D. G. Miralles, S. A. Montzka, C. Morice, 
J. Mühle, R. Myneni, J. P. Nicolas, J. Noetzli, T. J. Osborn, T. Park, A. Pasik, A. M. Paterson, M. S. Pelto, S. PerkinsKirkpatrick, G. Pétron, C. Phillips, B. Pinty, S. Po-Chedley, L. Polvani, W. Preimesberger, M. Pulkkanen, W. J. Randel, S. Rémy, L. Ricciardulli, A. D. Richardson, L. Rieger, D. A. Robinson, M. Rodell, K. H. Rosenlof, C. Roth, A. Rozanov, J. A. Rusak, O. Rusanovskaya, T. Rutishäuser, A. Sánchez-Lugo, P. Sawaengphokhai, T. Scanlon, V. Schenzinger, S. G. Schladow, R. W. Schlegel, E. Schmid, Martin, H. B. Selkirk, S. Sharma, L. Shi, S. V. Shimaraeva, E. A. Silow, A. J. Simmons, C. A. Smith, S. L. Smith, B. J. Soden, V. Sofieva, T. H. Sparks, P. W. Stackhouse, W. Steinbrecht, D. A. Streletskiy, G. Taha, H. Telg, S. J. Thackeray, M. A. Timofeyev, K. Tourpali, M. R. Tye, R. J. van der A, V. B. V. van der Schalie, Robin, G. van der Schrier, W. Paul, G. R. van der Werf, P. Verburg, J.-P. Vernier, H. Vömel, R. S. Vose, R. Wang, S. G. Watanabe, M. Weber, G. A. Weyhenmeyer, D. Wiese, A. C. Wilber, J. D. Wild, T. Wong, R. I. Woolway, X. Yin, L. Zhao, G. Zhao, X. Zhou, J. R. Ziemke and M. Ziese, Bull. Am. Meteorol. Soc., 2020, 101, S9-S128.

3 P. R. Yaashikaa, P. Senthil Kumar, S. J. Varjani and A. Saravanan, J. $\mathrm{CO}_{2}$ Util., 2019, 33, 131-147.

4 C. B. Hiragond, H. Kim, J. Lee, S. Sorcar, C. Erkey and S. In, Catal. Rev., 2020, 10, 1-21.

5 J. Qiao, Y. Liu, F. Hong and J. Zhang, Chem. Soc. Rev., 2014, 43, 631-675.

6 M. Papasizza, X. Yang, J. Cheng and A. Cuesta, Curr. Opin. Electrochem., 2020, 23, 80-88.

7 Z. Sun, T. Ma, H. Tao, Q. Fan and B. Han, Chem, 2017, 3, 560-587.

8 V. P. Indrakanti, J. D. Kubicki and H. H. Schobert, Energy Environ. Sci., 2009, 2, 745-758.

9 Y. Hori, in Modern Aspects of Electrochemistry, Springer New York, New York, NY, 2008, pp. 89-189.

10 A. J. Göttle and M. T. M. Koper, Chem. Sci., 2017, 8, 458-465.

11 J. Schneider, H. Jia, J. T. Muckerman and E. Fujita, Chem. Soc. Rev., 2012, 41, 2036-2051.

12 M. Gattrell, N. Gupta and A. Co, J. Electroanal. Chem., 2006, 594, 1-19.

13 A. A. Peterson, F. Abild-Pedersen, F. Studt, J. Rossmeisl and J. K. Nørskov, Energy Environ. Sci., 2010, 3, 1311-1315.

14 K. P. Kuhl, E. R. Cave, D. N. Abram and T. F. Jaramillo, Energy Environ. Sci., 2012, 5, 7050-7059.

15 W. Leitner, Angew. Chem., Int. Ed. Engl., 1995, 34, 22072221.

16 E. E. Benson, C. P. Kubiak, A. J. Sathrum and J. M. Smieja, Chem. Soc. Rev., 2009, 38, 89-99.

17 M. Abdinejad, C. Dao, B. Deng, F. Dinic, O. Voznyy, X. Zhang and H.-B. Kraatz, ACS Sustainable Chem. Eng., 2020, 8, 9549-9557.

18 M. Abdinejad, A. Seifitokaldani, C. Dao, E. H. Sargent, X. A. Zhang and H. B. Kraatz, ACS Appl. Energy Mater., 2019, 2, 1330-1335.

19 F. Li, Y. C. Li, Z. Wang, J. Li, D.-H. Nam, Y. Lum, M. Luo, X. Wang, A. Ozden, S.-F. Hung, B. Chen, Y. Wang, J. Wicks, Y. Xu, Y. Li, C. M. Gabardo, C.-T. Dinh, Y. Wang,
T.-T. Zhuang, D. Sinton and E. H. Sargent, Nat. Catal., 2020, 3, 75-82.

20 F. A. Almeida Paz, J. Klinowski, S. M. F. Vilela, J. P. C. Tomé, J. A. S. Cavaleiro and J. Rocha, Chem. Soc. Rev., 2012, 41, 1088-1110.

21 N. Elgrishi, M. B. Chambers, X. Wang and M. Fontecave, Chem. Soc. Rev., 2017, 46, 761-796.

22 L. Sun, V. Reddu, A. C. Fisher and X. Wang, Energy Environ. Sci., 2020, 13, 374-403.

23 X. Yang, J. Cheng, B. Fang, X. Xuan, N. Liu, X. Yang and J. Zhou, Nanoscale, 2020, 12, 18437-18445.

24 S. Zhao, S. Li, T. Guo, S. Zhang, J. Wang, Y. Wu and Y. Chen, Nano-Micro Lett., 2019, 11, 62.

25 I. Azcarate, C. Costentin, M. Robert and J.-M. Savéant, J. Am. Chem. Soc., 2016, 138, 16639-16644.

26 C. Costentin, S. Drouet, M. Robert and J. M. Savéant, Science, 2012, 338, 90-94.

27 E. A. Mohamed, Z. N. Zahran and Y. Naruta, Chem. Commun., 2015, 51, 16900-16903.

28 Y. Wu, J. Jiang, Z. Weng, M. Wang, D. L. J. Broere, Y. Zhong, G. W. Brudvig, Z. Feng and H. Wang, ACS Cent. Sci., 2017, 3, 847-852.

29 A. A. Al-Omari, Z. H. Yamani and H. L. Nguyen, Molecules, 2018, 23, 2835.

30 C. Costentin, S. Drouet, M. Robert and J.-M. Savéant, J. Am. Chem. Soc., 2012, 134, 11235-11242.

31 D.-H. Nam, P. De Luna, A. Rosas-Hernández, A. Thevenon, F. Li, T. Agapie, J. C. Peters, O. Shekhah, M. Eddaoudi and E. H. Sargent, Nat. Mater., 2020, 19, 266-276.

32 Y. Hori, Electrochemical CO2 reduction on metal electrodes, Modern aspects of electrochemistry, Springer, 2008, pp. 89189.

33 S. Nitopi, E. Bertheussen, S. B. Scott, X. Liu, A. K. Engstfeld, S. Horch, B. Seger, I. E. L. Stephens, K. Chan, C. Hahn, J. K. Nørskov, T. F. Jaramillo and I. Chorkendorff, Chem. Rev., 2019, 119, 7610-7672.

34 D. D. Zhu, J. L. Liu and S. Z. Qiao, Adv. Mater., 2016, 28, 3423-3452.

35 J. Liu, C. Guo, A. Vasileff and S. Qiao, Small Methods, 2017, 1, 1600006.

36 A. Vasileff, Y. Zheng and S. Z. Qiao, Adv. Energy Mater., 2017, 7, 1700759.

37 Y. Y. Birdja, E. Pérez-Gallent, M. C. Figueiredo, A. J. Göttle, F. Calle-Vallejo and M. T. M. Koper, Nat. Energy, 2019, 4, 732-745.

38 D. Gao, R. M. Arán-Ais, H. S. Jeon and B. Roldan Cuenya, Nat. Catal., 2019, 2, 198-210.

39 C. Costentin, M. Robert and J.-M. Savéant, Curr. Opin. Electrochem., 2017, 2, 26-31.

40 L. Zhang, Z.-J. Zhao and J. Gong, Angew. Chem., Int. Ed., 2017, 56, 11326-11353.

41 X. Zhang, Z. Wu, X. Zhang, L. Li, Y. Li, H. Xu, X. Li, X. Yu, Z. Zhang, Y. Liang and H. Wang, Nat. Commun., 2017, 8, 14675.

42 X. Cui, W. Li, P. Ryabchuk, K. Junge and M. Beller, Nat. Catal., 2018, 1, 385-397. 
43 C. L. Yao, J. C. Li, W. Gao and Q. Jiang, Phys. Chem. Chem. Phys., 2017, 19, 15067-15072.

44 N. Corbin, J. Zeng, K. Williams and K. Manthiram, Nano Res., 2019, 12, 2093-2125.

45 S. Lin, C. S. Diercks, Y.-B. Zhang, N. Kornienko, E. M. Nichols, Y. Zhao, A. R. Paris, D. Kim, P. Yang, O. M. Yaghi and C. J. Chang, Science, 2015, 349, 1208-1213.

46 C. Kim, H. S. Jeon, T. Eom, M. S. Jee, H. Kim, C. M. Friend, B. K. Min and Y. J. Hwang, J. Am. Chem. Soc., 2015, 137, 13844-13850.

47 X. Liu, P. Schlexer, J. Xiao, Y. Ji, L. Wang, R. B. Sandberg, M. Tang, K. S. Brown, H. Peng, S. Ringe, C. Hahn, T. F. Jaramillo, J. K. Nørskov and K. Chan, Nat. Commun., 2019, 10, 32.

48 Y. Mun, K. Kim, S. Kim, S. Lee, S. Lee, S. Kim, W. Choi, S. Kim, J. W. Han and J. Lee, Appl. Catal., B, 2018, 236, 154-161.

49 Z. Cao, J. S. Derrick, J. Xu, R. Gao, M. Gong, E. M. Nichols, P. T. Smith, X. Liu, X. Wen, C. Copéret and C. J. Chang, Angew. Chem., Int. Ed. Engl., 2018, 57, 4981-4985.

50 D. J. Abdallah and R. G. Weiss, Langmuir, 2000, 16, 352-355.

51 A. Thevenon, A. Rosas-Hernández, J. C. Peters and T. Agapie, Angew. Chem., Int. Ed., 2019, 58, 16952-16958.

52 Y. Kuwahara, D.-Y. Kang, J. R. Copeland, P. Bollini, C. Sievers, T. Kamegawa, H. Yamashita and C. W. Jones, Chem.-Eur. J., 2012, 18, 16649-16664.

53 D. M. D'Alessandro, B. Smit and J. R. Long, Angew. Chem., Int. Ed., 2010, 49, 6058-6082.

54 C. Ferrag, M. Abdinejad and K. Kerman, Can. J. Chem., 2019, 1, 1-8.

55 L. Chen, F. Li, Y. Zhang, C. L. Bentley, M. Horne, A. M. Bond and J. Zhang, ChemSusChem, 2017, 10, 4109-4118.

56 M. Abdinejad, C. Dao, B. Deng, M. E. Sweeney, F. Dielmann, X. Zhang and H. B. Kraatz, ChemistrySelect, 2020, 5, 979984.

57 M. Abdinejad, Z. Mirza, X. Zhang and H.-B. Kraatz, ACS Sustainable Chem. Eng., 2020, 8, 1715-1720.

58 P. V Danckwerts, Chem. Eng. Sci., 1979, 34, 443-446.

59 M. Caplow, J. Am. Chem. Soc., 1968, 90, 6795-6803.

60 O. S. Bushuyev, P. De Luna, C. T. Dinh, L. Tao, G. Saur, J. van de Lagemaat, S. O. Kelley and E. H. Sargent, Joule, 2018, 2, 825-832.

61 G. Zhao, X. Huang, X. Wang and X. Wang, J. Mater. Chem. A, 2017, 5, 21625-21649.

62 C. Anex, E. Touzé, L. Curet, F. Gohier and C. Cougnon, ChemElectroChem, 2019, 6, 4963-4969.

63 H. Liu, J. Chu, Z. Yin, X. Cai, L. Zhuang and H. Deng, Chem, 2018, 4, 1696-1709.

64 M. Isaacs, F. Armijo, G. Ramírez, E. Trollund, S. R. Biaggio, J. Costamagna and M. J. Aguirre, J. Mol. Catal. A: Chem., 2005, 229, 249-257.

65 D. Quezada, J. Honores, M. García, F. Armijo and M. Isaacs, New J. Chem., 2014, 38, 3606-3612.

66 N. Elgrishi, S. Griveau, M. B. Chambers, F. Bedioui and M. Fontecave, Chem. Commun., 2015, 51, 2995-2998.

67 X. Zhou, D. Micheroni, Z. Lin, C. Poon, Z. Li and W. Lin, ACS Appl. Mater. Interfaces, 2016, 8, 4192-4198.
68 C. Sun, L. Rotundo, C. Garino, L. Nencini, S. S. Yoon, R. Gobetto and C. Nervi, ChemPhysChem, 2017, 18, 32193229.

69 L. M. Aeshala and A. Verma, Macromol. Symp., 2015, 357, 79-85.

70 J. P. Collin and J. P. Sauvage, Coord. Chem. Rev., 1989, 93, 245-268.

71 C. Finn, S. Schnittger, L. J. Yellowlees and J. B. Love, Chem. Commun., 2012, 48, 1392-1399.

72 R. Francke, B. Schille and M. Roemelt, Chem. Rev., 2018, 118, 4631-4701.

73 G. F. Manbeck and E. Fujita, J. Porphyrins Phthalocyanines, 2015, 19, 45-64.

74 D. H. Apaydin, S. Schlager, E. Portenkirchner and N. S. Sariciftci, ChemPhysChem, 2017, 3094-3116.

75 H. Takeda, C. Cometto, O. Ishitani and M. Robert, ACS Catal., 2017, 7, 70-88.

76 A. Glüer and S. Schneider, J. Organomet. Chem., 2018, 861, 159-173.

77 D. C. Grills, Y. Matsubara, Y. Kuwahara, S. R. Golisz, D. A. Kurtz and B. A. Mello, J. Phys. Chem. Lett., 2014, 5, 2033-2038.

78 T. Zheng, K. Jiang and H. Wang, Adv. Mater., 2018, 30, 1802066.

79 H. Xie, T. Wang, J. Liang, Q. Li and S. Sun, Nano Today, 2018, 21, 41-54.

80 C. Kim, F. Dionigi, V. Beermann, X. Wang, T. Möller and P. Strasser, Adv. Mater., 2019, 31, 1805617.

81 D. M. Fernandes, A. F. Peixoto and C. Freire, Dalton Trans., 2019, 48, 13508-13528.

82 Y. Chen, S. Ji, C. Chen, Q. Peng, D. Wang and Y. Li, Joule, 2018, 2, 1242-1264.

83 Y. Hori, A. Murata, R. Takahashi and S. Suzuki, J. Am. Chem. Soc., 1987, 109, 5022-5023.

84 J.-M. Savéant, Chem. Rev., 2008, 108, 2348-2378.

85 A. Khadhraoui, P. Gotico, B. Boitrel, W. Leibl, Z. Halime and A. Aukauloo, Chem. Commun., 2018, 54, 11630-11633.

86 H. De Jesús-Cardona, C. del Moral and C. R. Cabrera, J. Electroanal. Chem., 2001, 513, 45-51.

87 Y. Hori, A. Murata and R. Takahashi, J. Chem. Soc., Faraday Trans. 1, 1989, 85, 2309-2326.

88 J. J. Kim, D. P. Summers and K. W. Frese, J. Electroanal. Chem. Interfacial Electrochem., 1988, 245, 223-244.

89 H. Sato, Energy Procedia, 2014, 63, 4031-4034.

90 I. Azcarate, C. Costentin, M. Robert and J.-M. Savéant, J. Phys. Chem. C, 2016, 120, 28951-28960.

91 J. Hawecker, J.-M. Lehn and R. Ziessel, J. Chem. Soc., Chem. Commun., 1984, 328-330.

92 T. H. T. Myren, A. M. Lilio, C. G. Huntzinger, J. W. Horstman, T. A. Stinson, T. B. Donadt, C. Moore, B. Lama, H. H. Funke and O. R. Luca, Organometallics, 2019, 38, 1248-1253.

93 J. D. Froehlich and C. P. Kubiak, Inorg. Chem., 2012, 51, 3932-3934.

94 A. Chapovetsky, T. H. Do, R. Haiges, M. K. Takase and S. C. Marinescu, J. Am. Chem. Soc., 2016, 138, 5765-5768. 
95 A. Chapovetsky, M. Welborn, J. M. Luna, R. Haiges, T. F. Miller and S. C. Marinescu, ACS Cent. Sci., 2018, 4, 397-404.

96 S. Kar, R. Sen, A. Goeppert and G. K. S. Prakash, J. Am. Chem. Soc., 2018, 140, 1580-1583.

97 N. Zouaoui, B. D. Ossonon, M. Fan, D. Mayilukila, S. Garbarino, G. de Silveira, G. A. Botton, D. Guay and A. C. Tavares, J. Mater. Chem. A, 2019, 7, 11272-11281.

98 A. Grondein and D. Bélanger, Fuel, 2011, 90, 2684-2693.

99 L. Ou, W. Long, J. Huang, Y. Chen and J. Jin, RSC Adv., 2017, 7, 11938-11950.

100 K. G. Schmitt and A. A Gewirth, J. Phys. Chem. C, 2014, 118, 17567-17576.

101 H. Coskun, A. Aljabour, P. De Luna, D. Farka, T. Greunz, D. Stifter, M. Kus, X. Zheng, M. Liu, A. W. Hassel, W. Schöfberger, E. H. Sargent, N. S. Sariciftci and P. Stadler, Sci. Adv., 2017, 3, e1700686.

102 S. Xin, Energy Environ. Sci., 2016, 9, 1687-1695.

103 J. Li, Y. Kuang, Y. Meng, X. Tian, W.-H. Hung, X. Zhang, A. Li, M. Xu, W. Zhou, C.-S. Ku, C.-Y. Chiang, G. Zhu, J. Guo, X. Sun and H. Dai, J. Am. Chem. Soc., 2020, 142, 7276-7282.

104 Y. Hori, K. Kikuchi, A. Murata and S. Suzuki, Chem. Lett., 1986, 15, 897-898.

105 Z.-Q. Liang, T.-T. Zhuang, A. Seifitokaldani, J. Li, C.-W. Huang, C.-S. Tan, Y. Li, P. De Luna, C. T. Dinh, Y. Hu, Q. Xiao, P.-L. Hsieh, Y. Wang, F. Li, R. QuinteroBermudez, Y. Zhou, P. Chen, Y. Pang, S.-C. Lo, L.-J. Chen, H. Tan, Z. Xu, S. Zhao, D. Sinton and E. H. Sargent, Nat. Commun., 2018, 9, 3828.

106 Y. Chen, K. Chen, J. Fu, A. Yamaguchi, H. Li, H. Pan, J. Hu, M. Miyauchi and M. Liu, Nano Mater. Sci., 2020, 2, 235-247.

107 Y. Zheng, A. Vasileff, X. Zhou, Y. Jiao, M. Jaroniec and S.-Z. Qiao, J. Am. Chem. Soc., 2019, 141, 7646-7659.

108 G. M. Tomboc, S. Choi, T. Kwon, Y. J. Hwang and K. Lee, Adv. Mater., 2020, 32, 1908398.

109 S. Kaneco, H. Katsumata, T. Suzuki and K. Ohta, Energy Fuels, 2006, 20, 409-414.

110 Y. Hori, I. Takahashi, O. Koga and N. Hoshi, J. Phys. Chem. $B, 2002,106,15-17$.

111 X. Lu, Y. Wu, X. Yuan, L. Huang, Z. Wu, J. Xuan, Y. Wang and H. Wang, ACS Energy Lett., 2018, 3, 2527-2532.

112 M. N. Hossain, S. Ahmad, I. Santos da Silva and H.-B. Kraatz, Chem.-Eur. J., 2020, DOI: 10.1002/ chem.202003039.

113 C. Sun, R. Gobetto and C. Nervi, New J. Chem., 2016, 40, 5656-5661.

114 C. S. Diercks, Y. Liu, K. E. Cordova and O. M. Yaghi, Nat. Mater., 2018, 17, 301-307.

115 X.-M. Hu, S. U. Pedersen and K. Daasbjerg, Curr. Opin. Electrochem., 2019, 15, 148-154.

116 D. M. Chisholm and J. Scott McIndoe, Dalton Trans., 2008, 3933-3945.

117 B. M. L. Dioos, I. F. J. Vankelecom and P. A. Jacobs, Adv. Synth. Catal., 2006, 348, 1413-1446.

118 K. Manthiram, B. J. Beberwyck and A. P. Alivisatos, J. Am. Chem. Soc., 2014, 136, 13319-13325.
119 J. Choi, P. Wagner, R. Jalili, J. Kim, D. R. MacFarlane, G. G. Wallace and D. L. Officer, Adv. Energy Mater., 2018, 8, 1801280.

120 R. W. Murray, A. G. Ewing and R. A. Durst, Anal. Chem., 1987, 59, 379A-390A.

121 A. N. Marianov and Y. Jiang, Appl. Catal., B, 2019, 244, 881888.

122 Y. Chen, C. W. Li and M. W. Kanan, J. Am. Chem. Soc., 2012, 134, 19969-19972.

123 C. A. Trickett, A. Helal, B. A. Al-Maythalony, Z. H. Yamani, K. E. Cordova and O. M. Yaghi, Nat. Rev. Mater., 2017, 2, 17045.

124 C. Yang, S. Li, Z. Zhang, H. Wang, H. Liu, F. Jiao, Z. Guo, X. Zhang and W. Hu, Small, 2020, 16, 2001847.

125 M. S. Xie, B. Y. Xia, Y. Li, Y. Yan, Y. Yang, Q. Sun, S. H. Chan, A. Fisher and X. Wang, Energy Environ. Sci., 2016, 9, 16871695.

126 D. Bélanger and J. Pinson, Chem. Soc. Rev., 2011, 40, 39954048.

127 A. Wang, W. Yu, Z. Huang, F. Zhou, J. Song, Y. Song, L. Long, M. P. Cifuentes, M. G. Humphrey, L. Zhang, J. Shao and C. Zhang, Sci. Rep., 2016, 6, 23325.

128 S. Baranton and D. Bélanger, J. Phys. Chem. B, 2005, 109, 24401-24410.

129 A. K. D. Dimé, A. Bousfiha and C. H. Devillers, Curr. Opin. Electrochem., 2020, 24, 69-78.

130 N. M. Orchanian, L. E. Hong, J. A. Skrainka, J. A. Esterhuizen, D. A. Popov and S. C. Marinescu, ACS Appl. Energy Mater., 2019, 2, 110-123.

131 M. Mooste, E. Kibena-Põldsepp, M. Marandi, L. Matisen, V. Sammelselg, F. I. Podvorica and K. Tammeveski, J. Electroanal. Chem., 2018, 817, 89-100.

132 J. W. Vickers, D. Alfonso and D. R. Kauffman, Energy Technol., 2017, 5, 775-795.

133 H. Mistry, R. Reske, Z. Zeng, Z.-J. Zhao, J. Greeley, P. Strasser and B. R. Cuenya, J. Am. Chem. Soc., 2014, 136, 16473-16476.

134 Y. Hori, H. Wakebe, T. Tsukamoto and O. Koga, Electrochim. Acta, 1994, 39, 1833-1839.

135 J. Tamura, A. Ono, Y. Sugano, C. Huang, H. Nishizawa and S. Mikoshiba, Phys. Chem. Chem. Phys., 2015, 17, 2607226078.

136 Y. Fang and J. C. Flake, J. Am. Chem. Soc., 2017, 139, 33993405.

137 D. R. Weinberg, C. J. Gagliardi, J. F. Hull, C. F. Murphy, C. A. Kent, B. C. Westlake, A. Paul, D. H. Ess, D. G. McCafferty and T. J. Meyer, Chem. Rev., 2012, 112, 4016-4093.

138 R. Vaidhyanathan, S. S. Iremonger, G. K. H. Shimizu, P. G. Boyd, S. Alavi and T. K. Woo, Science, 2010, 330, 650-653.

139 Z. Cao, D. Kim, D. Hong, Y. Yu, J. Xu, S. Lin, X. Wen, E. M. Nichols, K. Jeong, J. A. Reimer, P. Yang and C. J. Chang, J. Am. Chem. Soc., 2016, 138, 8120-8125.

140 W. Zhu, R. Michalsky, Ö. Metin, H. Lv, S. Guo, C. Wright, X. Sun, A. A. Peterson and S. Sun, J. Am. Chem. Soc., 2017, 139, 9408. 
141 X. Feng, K. Jiang, S. Fan and M. W. Kanan, J. Am. Chem. Soc., 2015, 137, 4606-4609.

142 A. Hamelin, J. Electroanal. Chem. Interfacial Electrochem., 1984, 165, 167-180.

143 A. Hamelin and J. Lipkowski, J. Electroanal. Chem. Interfacial Electrochem., 1984, 171, 317-330.

144 T. Hatsukade, K. P. Kuhl, E. R. Cave, D. N. Abram and T. F. Jaramillo, Phys. Chem. Chem. Phys., 2014, 16, 1381413819.

145 H. Li, P. Wen, D. S. Itanze, Z. D. Hood, X. Ma, M. Kim, S. Adhikari, C. Lu, C. Dun, M. Chi, Y. Qiu and S. M. Geyer, Nat. Commun., 2019, 10, 5724.

146 J. Xiao, H. B. Li, W. Q. Zhou, N. Q. Luo, Y. Liang, J. M. Shao, P. Liu, X. Y. Zou, Z. Dai and G. W. Yang, RSC Adv., 2013, 3, 20532-20537.

147 L.-X. Wu, Y.-G. Zhao, Y.-B. Guan, H. Wang, Y.-C. Lan, H. Wang and J.-X. Lu, RSC Adv., 2019, 9, 32628-32633.

148 Q. Lu, J. Rosen, Y. Zhou, G. S. Hutchings, Y. C. Kimmel, J. G. Chen and F. Jiao, Nat. Commun., 2014, 5, 3242.

149 S. Liu, H. Tao, L. Zeng, Q. Liu, Z. Xu, Q. Liu and J.-L. Luo, J. Am. Chem. Soc., 2017, 139, 2160-2163.

150 A. Maurin and M. Robert, J. Am. Chem. Soc., 2016, 138, 2492-2495.

151 S. Aoi, K. Mase, K. Ohkubo and S. Fukuzumi, Chem. Commun., 2015, 51, 10226-10228.

152 X. M. Hu, M. H. Rønne, S. U. Pedersen, T. Skrydstrup and K. Daasbjerg, Angew. Chem., Int. Ed., 2017, 56, 6468-6472.

153 S. Zhang, P. Kang, S. Ubnoske, M. K. Brennaman, N. Song, R. L. House, J. T. Glass and T. J. Meyer, J. Am. Chem. Soc., 2014, 136, 7845-7848.

154 S. Verma, B. Kim, H.-R. "Molly" Jhong, S. Ma and P. J. A. Kenis, ChemSusChem, 2016, 9, 1972-1979.
155 M. Zhong, K. Tran, Y. Min, C. Wang, Z. Wang, C.-T. Dinh, P. De Luna, Z. Yu, A. S. Rasouli, P. Brodersen, S. Sun, O. Voznyy, C.-S. Tan, M. Askerka, F. Che, M. Liu, A. Seifitokaldani, Y. Pang, S.-C. Lo, A. Ip, Z. Ulissi and E. H. Sargent, Nature, 2020, 581, 178-183.

156 R. Lin, J. Guo, X. Li, P. Patel and A. Seifitokaldani, Catalysts, 2020, 10, 473.

157 D. M. Weekes, D. A. Salvatore, A. Reyes, A. Huang and C. P. Berlinguette, Acc. Chem. Res., 2018, 51, 910-918.

158 M. Jouny, W. Luc and F. Jiao, Nat. Catal., 2018, 1, 748-755. 159 K. Lin, Q. Chen, M. R. Gerhardt, L. Tong, S. B. Kim, L. Eisenach, A. W. Valle, D. Hardee, R. G. Gordon, M. J. Aziz and M. P. Marshak, Science, 2015, 349, 1529-1532. 160 C.-T. Dinh, T. Burdyny, M. G. Kibria, A. Seifitokaldani, C. M. Gabardo, F. P. García de Arquer, A. Kiani, J. P. Edwards, P. De Luna, O. S. Bushuyev, C. Zou, R. Quintero-Bermudez, Y. Pang, D. Sinton and E. H. Sargent, Science, 2018, 360, 783-787.

161 M. Abdinejad, C. Dao, X. Zhang and H. Bernhard Kraatz, J. Energy Chem., 2020, DOI: 10.1016/j.jechem.2020.09.039.

162 B. Endrődi, G. Bencsik, F. Darvas, R. Jones, K. Rajeshwar and C. Janáky, Prog. Energy Combust. Sci., 2017, 62, 133-154.

163 R. Kortlever, J. Shen, K. J. P. Schouten, F. Calle-Vallejo and M. T. M. Koper, J. Phys. Chem. Lett., 2015, 6, 4073-4082.

164 S. Ren, D. Joulié, D. Salvatore, K. Torbensen, M. Wang, M. Robert and C. P. Berlinguette, Science, 2019, 365, 367369.

165 K. Torbensen, C. Han, B. Boudy, N. von Wolff, C. Bertail, W. Braun and M. Robert, Chem.-Eur. J., 2020, 26, 30343038. 